\title{
The psychology of poverty
}

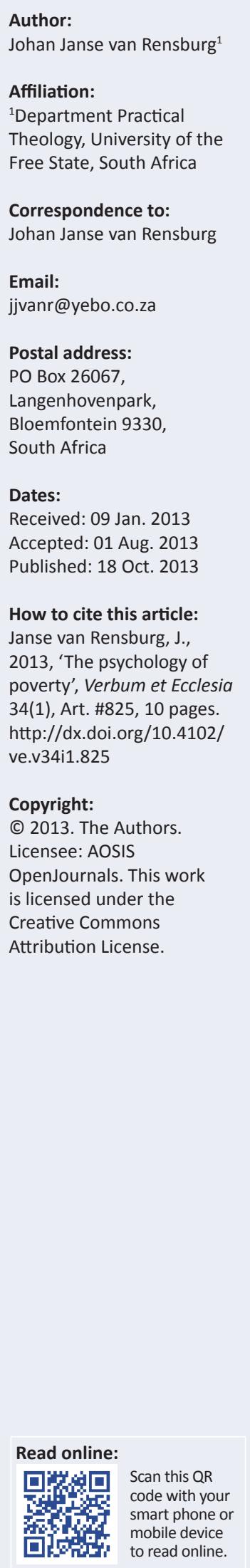

This article investigates the psychological experience of poor people and the pastoral responsibility to guide them towards poverty transition. A qualitative analysis of the narratives of three participants is compared to the enthralling history of Florcy Mabuza who in her book, Poverty mentality: The root of poverty, explains the dangers of a spiritual and emotional mindset that precipitates and feeds the plight of poverty. Using a literature study to interpret the narratives as well as a method of encoding, basic mindsets of poverty and factors that influence this mindset are identified. The study culminates in conclusions to encourage further research and pastoral involvement.

\section{Introduction}

When investigating the phenomenon of poverty, the question is not only why people are poor, but also, and most importantly, why people remain poor. Why is it that poverty seems to keep people in some kind of psychological bondage from which they are unable to escape? Sometimes all efforts to help an individual, a family or a community to break the bonds of poverty are fruitless. It seems to be undisputable that we may also speak of the psychology behind poverty. This article will endeavour to research the inner driving forces of poverty that not only create poverty but also sustain a situation of poverty. Of course, it is not suggested that the psychological aspect of poverty is the only influence. Many other variables like systemic issues and economic and political factors also play an important role in precipitating or feeding the destructive cycles of poverty. In fact, the method of encoding in the narrative approach as well as consulted literature will show the inter dynamics between these factors and the psychological. The point of departure here is, however, the psychological aspect.

Special mention must be made of the fact that any objections against the use of terms like 'poor people', 'poverty-stricken people' and 'the poor' does not hold ground, although one understands the sentiment behind such objections. ${ }^{1}$ Scientific literature on poverty reflects overwhelmingly that the terms 'poor people' and 'the poor' are used freely and without reservation (see e.g. Haughton \& Khandler 2009:1; Narayan \& Petesch 2007:15). To give a definition of poverty would attempt the impossible, since poverty includes so many aspects and dimensions. Although the focus is on material impoverishment, the premise of the article is precisely that spiritual and mental poverty could hold people in the bondage of poverty. A Positive mentality, on the other hand could empower them to break through boundaries.

\section{Research problem}

Why is it, by way of example, that someone is given an opportunity to sever himself or herself from the predicament of poverty, yet the person rejects or disregards the created opportunity and willingly chooses to fall back into the quicksand of poverty? According to Grootart, Kanbur and Oh (1999:14-16), people with few children, with youth on their side and holding some kind of qualification have a better chance of escaping poverty. However, this assumption does not always hold ground. Consider, for example, the case of a man and his girlfriend (they were not married) who started attending church. During a pastoral discussion the man expressed the need to find work. Miraculously, a good job was secured for him within one week, since he was a qualified mechanic. He could start immediately with a salary of over R3000 per month. All went well for a few months, but then the man absconded with a new girlfriend, leaving the other woman behind and moving to the next situation of poverty.

All the above prerequisites for stepping out of poverty were there, yet the man chose adventure and poverty before sanity and good living conditions. What causes people to make such wrong choices? It seems as though incidents like this one confirm the theory of Mullainathan,

1.Whilst presenting a paper on poverty at the workshop for Practical Theology at Stellenbosch, 21-22 January 2010, some who attended the presentation advised that the term 'poor people' should be avoided. 
professor of economics at Harvard University (2012), that poor people sometimes make the wrong financial decisions because of their need for some kind of enjoyment to alleviate the hardships of poverty. They grasp at happiness for the moment without being able to consider the consequences in the long term.

This theory is supported by other research projects. Magezi (2007:52) has found that migrant labourers in the South African mining industry, living under poor and appalling conditions, yearned for 'some measure of comfort and relief from the harsh realities of the mining existence', and, in order to achieve this, engaged in casual sex with prostitutes, thereby causing the spread of HIV and AIDS. In another project, social psychologists developed a theory of 'depletable' self-control. The theory builds on the assumption that people are inclined to exert willpower in some situations, which will probably make them more vulnerable to give in to temptations in other areas or situations (Holmes 2011:1-2). Chris Blattman (2009) follows the same line of reasoning.

Also in 2011, Mullainathan identified the scarcity of cognitive resources $^{2}$ as a major contribution to people's inability to make correct decisions (2011:19-22). In addition, psychologist Martin Seligman (2011) introduced the concept of 'learned helplessness' which, in the final analysis, means that the person has been conditioned to be unable to act in such a way that positive results could be achieved. This inability could lead to emotional distress, according to Seligman. These are but a few of many possible explanations for poor people's seeming inability to escape poverty.

Other questions are equally important. What psychological profiles could be encoded from the narratives of people who are caught up in situations of poverty? Does poverty change people psychologically? When are psychological pathologies the cause of poverty and when are they its result? Can these negative tendencies and driving forces be addressed in a pastoral process? These and many more such questions profile the goal of this research. Modesty should, however, be the operative word, for such research can only hope to scratch the surface of a never-ending chain of cause and effect.

\section{Hypotheses}

The article will be guided by the following hypothesis:

- Hypothesis: A better understanding of psychological dynamics is indispensable in a holistic approach to pastoral counselling with people in a context of poverty.

In previous articles a holistic approach to pastoral counselling was extensively argued (Janse van Rensburg 2009, 2010, Janse van Rensburg \& Breedt 2011). A holistic approach includes all dimensions of a person's life (Clinebell [1984] 1987:25-51), thereby implying that the psychology of poverty simply may not be neglected or excluded. Sadly, this aspect has been a somewhat ignored field in the pastoral practice. Carr and 2.A link between cognitive and psychological functions is presumed in the article.
Sloan (2003:5-6) are convinced that the role of psychology in research on poverty 'became more a part of the problem than of the solution', resulting in psychology struggling to find a way to make any kind of contribution to understanding and reducing poverty.

However, it seems as though the importance of psychology in addressing poverty is gaining ground in research. The American Psychological Association has adopted a resolution encouraging psychologists to focus on the problem of poverty in a structured manner by introducing research, knowledge and experience to make a significant contribution $\left(\mathrm{O}^{\prime} \mathrm{Conner}\right.$ 2001:81). Eldar Shafir, professor at Princeton University and advisor to the President of the USA, Barak Obama, says: 'Poverty is to a large extent an emotional state' (Shafir 2012). According to Shafir, society sends out a message that poor people are not good enough. 'You're poor because you're no good.' This creates feelings of inferiority since it is very easy for people in a particular predicament to accept this kind of thinking. To which Shafir comments: 'The poor aren't less able, they're distracted.' His hypothesis is that emotional distractions can cause people to make the wrong decisions, leading up to poverty.

From this main hypothesis it is further assumed that, since people are alike, people in a context of poverty would basically feel, reason, and act in the same way. It is therefore envisaged that the narratives of a selected group would be analysed with the aim of encoding psychological and sociological dynamics that play a role, either in stimulating and creating a situation of poverty, or enforcing a context of poverty. Perlman (2007:228) describes this as 'life history narratives with openended in-depth interviews and participating observation'. Warning against an overemphasis on quantitative research, Narayan and Petesch (2007:11) argue that such an approach inevitably gives a one-dimensional approach by focussing on economical statistics, thereby ignoring psychological and sociological factors in the cause of poverty. Thus, it follows that a qualitative approach will serve the goals of this research more adequately.

\section{Goals of the research}

The goal of this research is first of all to better understand the psychological factors behind a context of poverty. How do people feel and reason in a context of poverty? With this main goal as point of departure, the research will endeavour to encode such psychological driving forces that could be labelled as general psychological tendencies.

\section{Methodology}

A literature study will be an important part of the research. Literature dealing with or touching on the themes of poverty, psychology and sociology will be consulted. Where applicable there will also be engagement with pastoral theology. With the guidelines identified, a qualitative investigation will listen to the brief narratives of people with a history of poverty, in order to encode general psychological 
tendencies in these narratives. According to Johnson and Christensen (2008:413), open coding in qualitative research is the first stage in grounded theory after initial data have been collected and examined. In the process of open coding a certain experience or emotion could be identified which seems to be the most prominent in a particular participant's narrative.

Pieterse (2010:113-129) explained and used the method of encoding successfully in qualitative research. Following the grounded theories of Glazer (1978) and Charmaz (2006) and pursuing the goals of the research group of Gerrit Immink (Pieterse 2010:114), the 'bottoms-up approach' analyses raw material in order to formulate theories for praxis. From this point of departure the process of encoding builds on the experience of the participants in a qualitative action research. Another example of such a bottoms-up approach, starting from the narratives of people, is found in the research of Curran (2002:365-386). Examining the reports of social workers during the post-war period regarding the position of single mothers and children, a psychology of poverty was developed to protect women and children from accusations of immorality and the refusal of the government of the day to grant social assistance.

In the article at hand, the qualitative process will start with the wonderful narrative of Florcy Mabuza as told in her book with the significant title: Poverty mentality: The root of poverty (2010). Against the backdrop of this narrative basic emotions and thoughts on the experience of poverty will be encoded from the narratives of participants. Care will be taken not to enforce the encoding of Mabuza's narrative on the emotions of participants. In analysing the data from interviews, the encoded emotions in Mabuza's narrative will be used as a control system to juxtapose the encoded psychological responses of the other participants' narratives. It is hoped that this method will give a reasonably accurate indication of the psychological, emotional and mental factors that serve as driving forces in creating or sustaining situations of poverty (Pieterse 2009:267).

\section{An epistemological challenge}

Although the introduction of a psychological dimension to the discussion on poverty seems to be a natural and much needed contribution, it is not altogether without epistemological complications. In his quest to identify themes in preaching on poverty, Hennie Pieterse (2010:116) chooses to work with a grounded theory through the formulation of new concepts 'out of raw material in qualitative research'.

Pieterse also refers to the work of Osmer (2008) in explaining his methodology. Explaining the core task of practical theology, Osmer (2008:4-29) works with four questions, which leads him to identify the core task as the empirical or descriptive task ('What is going on?'); the normative task ('What should be going on?'); the interpretative task ('Why is this going on?') and the pragmatic task ('How should we respond?').
Although Osmer succeeds in explaining how all these tasks are intertwined, it is not without complications. For example, the empirical task of practical theology aims to establish what is going on in a particular situation. If the psychology of poverty is the focus of research, it would rightfully suggest that an analysis of the de facto situation is to be made. Yet a 'bottoms-up' or qualitative approach is not designed nor does it intend to establish empirical facts, since qualitative research deals with the emotions, perceptions and interpretations of the history of individuals and families (Pieterse 1993:72). It is therefore a narrative hermeneutic approach, which differs from a quantitative interpretation of facts and figures (Mouton 1993:53-75). There are two reasons for this choice. Firstly, it becomes apparent from a study by Meth (2011:4) that there are many pitfalls in a quantitative methodology of research on poverty, amongst others the fact that figures and interpretations are not always reliable. Secondly, the purpose of the research is focussed on psychological factors like emotions and mindset, not statistics.

Returning to the model of Osmer, from a qualitative interpretation of 'raw material' it would be difficult to establish 'what is going on' or 'what should be done', as per Osmer's model. Nevertheless, it does seem inevitable that psychological factors require attention in order to come closer to an understanding of the underlying psychological driving forces of people living in poverty, since humans are interpretive beings (Osmer 2008:21). In this particular research people living with poverty will be asked to narrate their stories in the hope that emotions and psychological driving forces are revealed. The results of this qualitative process will not produce more than tendencies in psychological responses. Such tendencies are then encoded and interpreted, in order to move pastoral theology towards a better understanding of the actions and responses of people living in poverty.

The important distinction that Osmer (2008:163-173) makes between inter-disciplinary dialogue, intra-disciplinary dialogue, multi-disciplinary dialogue and meta-disciplinary dialogue will therefore not function prominently in this research. However, where applicable, inter-disciplinary comments and insight will be acknowledged.

More or less on the opposite side of this empirical approach is Daniël Louw (2010:69-70) who sides with authors that warn against the psychologisation of pastoral care and spirituality. He fears that the over-emphasis on psychology could have a negative impact on the character and quality of pastoral counselling and therapy. A pre-occupation with psychological undertones and efforts to reinforce personality strengths against weaknesses may lead to other psychological disturbances such as individualism, spiritual narcissism and pragmatism, writes Louw.

Another danger in introducing psychological motives must also be mentioned. According to Louw (2010:69) it could lead to a paradigmatic reduction 'from the spiritual realm 
to the realm of behaviour with the emphasis in research on the living human document', thereby causing the spirituality of pastoral care and counselling to be jeopardised. For some time and in many publications, Louw (1993a, 1993b, 1998) has perpetually warned against this meta-theoretical reductionism. Louw (1999:50) argues that the principles of Scripture operate as a preventative measure to insure that the pastoral character is not substituted by human techniques.

In evaluating these two seemingly opposing epistemological choices, it is my understanding that both these points of view have merit. The warning against a reduction in the spirituality of pastoral processes should be taken seriously. A choice for a practical theological epistemology could lead to a devaluation of the theological character of pastoral care and counselling (Janse van Rensburg 2000:93-94). Where practical theology finds its research methodology in the social sciences, it could lead to empiricism (Heitink 1993:106). Special care and attention should therefore be given to the pastoral character of therapy and counselling, in order to prevent the process from becoming 'psychological sessions with clients'.

However, anthropology that treats a human being as a holistic being implies that body, mind, psyche and any other function that could be singled out, make up the whole human existence. Osmer (2008:15) speaks of this as the 'interconnectedness of ministry'. We may therefore conclude that a pastoral approach to poverty that does not include psychological dimensions may not be presented as a holistic pastoral process. In his book Widening the horizons (1986) Gerkin has helped a great deal to explain the balance between the theological character of pastoral counselling and the dynamic interaction with every new individual context. Within his definition, Gerkin (1986) explains that:

practical theology is the critical and constructive reflection on the life and work of Christians in all the varied contexts in which that life takes place with the intention of facilitating transformation of life in all its dimensions in accordance with the Christian gospel. (p. 61)

Analysing the chosen methodology of Pieterse (2010:118, 120-126), there could be no doubt that the theological character of practical theological actions operating from this grounded theory could do so without necessarily jeopardising the religious and ethical contexts of the pastoral process. This becomes apparent when Pieterse (2010:113) utilises the strategy of Charmaz, despite the fact that it is a social constructionist (post-modern) approach. Moreover, Bezuidenhout and Janse van Rensburg (2006:1743) elaborately explain how the narrative therapy of social constructionism could be deconstructed and reconstructed within a diaconiological approach.

\section{The matrix for a poverty mentality}

In my introduction I have already indicated why the narrative of Florcy Mabuza (2010) is used as a matrix to identify patterns of a poverty mentality. Here we have the compelling story of someone who has been there and who survived to tell, so that others may benefit from her experience. The mentality patterns that she identifies will be highlighted and briefly discussed. It will then serve as a matrix for the rest of the qualitative participants.

\section{Religious ambivalence}

Because of the harsh and merciless treatment she experienced from her father at home, Florcy was emotionally damaged and miserable. This caused her to feed her mind with negative thinking about God and the Bible. However, gradually her resentment of faith and Word was changed. Referring to Romans 12:2, she believes that the transformation was initiated by God. She writes: 'God transformed my life by the renewing of my mind' (Mabuza 2010:4). Reading her book, one comes under the impression of her deeply rooted faith in Jesus Christ and the Bible. Many passages of Scripture serve as a basis for challenging those who are caught up in a poverty mentality. This strong basis of faith and scriptural knowledge will be tested in the narratives of the qualitative participants. What is their religious understanding and experience of their struggle with poverty? Do they blame God for their predicament? What role (if any) do faith, religion and the Bible play in coping with the dilemma of poverty?

\section{An independent mentality}

For reasons explained in her narrative, Florcy felt rejected and unloved. She felt that she did not fit in. This made her determined to take responsibility for her own life, not wanting or expecting help from others. Subsequently, she also rejected the idea that God could or would help her. This she identifies as deception - a very subtle mentality of distrust, not believing people or even the Bible (Mabuza 2010:40-45). Such a mentality strengthens a poverty mentality. Quoting Proverbs 13:18 she explains: 'Poverty and shame shall be to him who refuseth instruction ...' (Mabuza 2010:64-65). Losing her self-worth and self-love, she experienced selfrejection and lost confidence in herself (Mabuza 2010:11-13). Clearly, we find strong and opposing psychological drives in this narrative. One can only conclude that Florcy had a strong personality to drive her forward, despite these conflicting negative mentality-patterns. How else would she have been able to attain two academic degrees and rise above her circumstances?

\section{Self-condemnation}

In Florcy's narrative the realisation of poverty brought shame. Shame caused her to act according to her degrading feelings of herself and her poverty. The result was feelings of helplessness. She calls it an 'I can't do it' mentality. Because of fear of rejection:

your poverty mentality will convince you that you are alright where you are. Deep down in your spirit you know that you are called to move from where you are but you are afraid and not willing to take one step forward. A poverty mentality will cause you to run away from your hopes and desires. (Mabuza 2010:66-67) 
'The fear has convinced you to stay where you are' (Mabuza 2010:49). Very often people in this frame of mind take refuge in manipulation strategies, using tears to get what they need. She explains (Mabuza 2010):

Self-pity will convince you that there is no way you can move forward from where you are, and that you should just be thankful to God for the little or the nothing that you have now. (p. 31)

This vicious circle is explained as a confirmation of the words of Proverbs 23:7: 'For as a man thinks in his heart, so is he' (Mabuza 2010:25).

\section{Three narratives of poverty}

The interviews with three participants were conducted in an informal way. Although the story of Florcy Mabuza functioned as the backdrop for the direction of the interviews, an informal and open-ended approach was used to ask introductory questions and follow-up questions, with the possibility of a wide horizon of answers. Careful attention was given not to influence answers by the formulation of questions, in order to secure answers that could lead to the open coding (Johnson \& Christensen 2008:412-413) of the respondent's answers. A brief narrative of the three participants will now be given. Names used are with permission of the participants.

\section{Stanley Botha}

Stanley is a 52-year-old White male, married to Michelle, a mentally retarded woman. Living with his parents in his youth probably served as an introduction to poverty. Nevertheless, he reports having good memories of the early years. He did quite well playing rugby for a club. He enjoyed the company of co-players and socialised with them, having a few drinks after matches. His life was uncomplicated and although he was not wealthy, he had enough to live on. This was a very happy time in his life. His life took a turn for the worse when, under pressure of his parents, he had to return home to work close to his parents. This job did not last long and he had to move from one job to the next. Shortage of money and bitterness - because he gave in to the pressure of his parents to return home - caused bouts of severe drinking. He started to blame his father and mother, brothers and sisters for his deteriorating life quality. Disappointment in the turn of events (a promising life turned bad) either precipitated or worsened feelings of self-resentment. Becoming an alcoholic was inevitable. Because of alcohol dependency he attempted to commit suicide. He missed the fellowship he enjoyed with his fellow rugby players because they loved and accepted him. A strong need for acceptance developed - an emotion that could not be satisfied because of his addiction. When Stanley and his wife came to the Andrew Murray congregation begging for food, they were told that they would be given a food parcel on a regular basis but that the congregation would prefer them to come to church regularly and become part of the Christian family. They now experience the unconditional acceptance of congregation members. Their living conditions have improved slightly because of a job as car watch, which he has kept for most of the time. This job enabled him to regain pride and confidence. He has had several relapses of alcoholism but with the support of congregation members he has recovered each time. Stanley saved some money to buy an electric guitar and a sound system. He has just made a CD, singing the country songs that he loves so much. This has given a lot of joy and confidence and a new reason for living. He enjoys life despite basic poverty still being part of his life. He has recently started recording a second CD.

\section{Hannatjie Pretorius}

At the age of 8 months and 6 days Hannatjie was taken to a children's home. She never found out what caused this action that had such a great influence on her life. She recalls that she was often locked inside a dark room because she was told that she was bad. Later she was placed in her grandparents' care. Those were difficult years. Nevertheless they had food to eat and were taken care of. At the age of 14 she was placed back in her parents' care. Because of her mother's illness, most of the little money they had was spent on medication. When Hannetjie was 17, she fell pregnant with a son and stayed with her parents until the age of 21. She got married to a man who mistreated her and her son. This violence was reported and he was removed by the police. After divorcing this man, she remarried a man who was deaf and dumb and only received a small pension, leading her into the next situation of poverty. They ensured a little income by doing handy work together. After a marriage of 18 years her husband was killed in a train accident. Two years later she remarried for the third time. This was another disaster with the marriage not securing the basic living needs. She divorced this man after 4 years and was left with nothing. Currently she rents a room in an old house with her aged father, her retarded son and other people.

\section{Louise Swanepoel}

Louise reports having had happy years as a child. The family was not strong financially but were content with what they had. Her parents secured a safe haven for her. They were married for 50 years and were dedicated Christians, teaching their children to fear the Lord. She reports sometimes having feelings of bitterness because she could not have what other children had. Those were never very intense feelings. However, at the age of 14 she developed strong feelings of aggression against God, feeling that God was not interested in helping her. She did not discuss these feelings with anyone since she reports having an introvert personality. They were often visited by a minister but their poverty predicament was never discussed. At the age of 21 she married a man of little means. He had a secure job and a fair income but most of the salary was wasted due to alcohol abuse. The alcohol dependency became so severe that Louise could not stand it anymore. After 21 years of marriage they were divorced. Her situation then gradually worsened since she could not secure work and her husband refused to pay alimony. The children were placed in foster care and later stayed with the divorced husband. Louise rented a room and became a car 
watch to pay for the rent. During this difficult time she was supported by her mother and sister with what little means they had. She reports that no church showed interest in her or supported her in any way. She started working as a car watch at the Dutch Reformed Church Andrew Murray. She was paid well by members and many took special interest in her as a person. The church paid her a small salary above and beyond the tips she received. Eventually, she indicated that she would want to become a member of the congregation. She was appointed as house mother for poor homeless people. Her living conditions and her well-being improved substantially.

\section{Encoding the narratives \\ Social structures predominantly influence the creation of poverty}

Qualitative research done by Doss (2011:148) clearly reveals the link between poverty and social structures. According to narratives of participants, social anguish is precipitated not so much by the need for food or possessions, but by social and relational issues. Because of social stigmas of poverty, the tradition of caring seems to be relinquished, thus creating feelings of abandonment and isolation.

It seems as though there is a significant mobility into and out of poverty, influenced mostly by socio-economic, regional and psychological factors (Grootart et al. 1999:2-12). Narayan and Petesch (2007:1) comment that research on the reasons why some succeed in stepping out of poverty, whilst others remain in chronic poverty is still in its infancy. They indicate that social structures (or the lack thereof) seem to play a more predominant role than personal issues (2007:6-7). Individuals frequently act as members of a household and the strategies of families within a poverty context (2007:8).

This theory is supported by Perlman (2007:228-230). Conducting qualitative interviews, he established that poverty could be linked to as much as four generations of social structures and the struggle to survive in them. Perlman (2007:243) concludes that social issues like communitybased violence (see also Streck 2003:203), drug abuse, crime, gangsterism and political obstacles like the lack of voice, lack of trust and lack of community unity function largely as barriers that prevent poverty transition. Social prejudice, argue Lemmieux and Pratto (2003:148-149), often caused by a lack of hygiene, illness and disease causes people to avoid situations of poverty, thus creating a social barrier. Poor people can feel this stigmatising and tend to avoid social interaction. McClure (2012:1-20) feels so strongly about the influence of social contexts in pastoral counselling that he urges us to move away from individualism in order to become more aware of the influence of social dynamics in counselling.

In many ways Florcy Mabuza (2010) is a representative of the narratives of Black people, having been born into poverty because of the socio-political structures in South Africa.
Such political and social structures could be associated with what Narayan and Petesch (2007:11-13) call inequality traps. Although her parents were able to secure a good home and enough to eat, she also reports terrible stories of poverty amongst her own people (Mabuza 2010:1-4) She had to leave South Africa at the age of 15 during the apartheid years to seek a good education in a neighbouring country.

Such negative social contexts are, however, not exclusively politically determined. As Perlmen indicated, poverty often becomes a pattern through four generations or more. In the case of all three participants in this research a history of poverty preceded them. In all cases it was social structures, mostly family ties that caused them to be poor. Lemmieux and Pratto (2003:147) point out that it is relations within social structures that determine how people distribute resources. This was apparent in the narratives of the participants. In not one of the three cases were the dominant causes of poverty their own doing. Stanley was emotionally manipulated to return to his parents and poor living condition. Louise married an alcoholic and was forced to divorce, causing her to move into a next cycle of poverty (see the remarks on the influence of alcohol abuse as a social barrier to poverty transition in Streck 2003:205) and Hannatjie had a history of family poverty her whole life.

The American Society of Psychology has adopted a resolution which confirms that ' $[p]$ sychologists, in their roles as researchers, service providers, educators and policy advocates, are perfectly situated to understand the societal causes and consequences of poverty' (O'Connor 2001:81). It is precisely the social influences holding people in bondage of poverty that make it so difficult for pastoral intervention towards poverty transition. After all, one can do nothing to undo the past; one can only attempt to cure the scars caused by the past in order to secure a better future.

\section{An individual mindset should not be underestimated}

Florcy Mabuza's narrative illustrates the importance of an independent positive mindset which enabled her to attain two academic degrees despite feelings of inferiority and the many drawbacks of poverty (see the discussion above). However, she did not always have this positive mindset. She reports feelings of self-rejection and shame, negative thoughts, and self-condemnation as characteristics of her poverty mentality (2010:12-26). She explains: 'Self-pity will convince you that there is no way you can move forward from where you are ...' (Mabuza 2010:31). Indeed, Prilleltensky (2003:77-79) equates such a negative mindset with psychological injuries and warns that these may cause trauma and even more serious psychopathology.

Taking the three narratives of the participants into consideration, all three confirm the importance of a positive mindset in poverty transition. Without the availability of transport Stanley walked more than $10 \mathrm{~km}$ per day to get to the place where he had a job as car watch. This shows great 
determination. He was also motivated to pursue his ideal of singing and recording, something which he achieved on his own without any support or financial help. Despite poor health, Hannatjie also took a job as car watch. With the little money that she earned, she took responsibility for her aged father and retarded son. Louise in particular showed a positive mindset in moving from car watch to taking up the responsibility of caregiver and cook for homeless poor people. In all three cases their living conditions were able to improve, little as it may have been, because of their willingness to do something about their predicament.

To a large extent it may be true that social structures play a dominant role. It seems as though social structures would be the dominant factor in incarcerating people in cycles of poverty, whilst a personal mindset is the dominant factor to empower people to step out of the stronghold of poverty. Perlman (2007:228) for example stresses the fact that some people were able to overcome obstacles because of high aspirations and a sense of urgency, optimism and perseverance. He calls this 'the mindset', which refers to attitudes of fatalism or optimism and the feeling of being worse off than others (2007:252).

There could be no dispute that there is a strong correlation between mindset and the ability or inability to move out of the cycle of poverty. Perlman (2007) explains:

People who believed that whatever happened was destined to occur ... were less likely to be proactive in seeking opportunities, less likely to have strategies for getting ahead, thus less likely to succeed. (p. 250)

This seems to correspond with the conviction of Narayan and Petesch (2007:22) that a social structural endeavour like employment by public and private sectors only play a minor role in poverty transition. However, it seems that Haughton and Khandler (2009:4) disagree that employment plays only a minor role. They conclude that 'a good poverty profile also makes employment targeting possible'. For a positive mindset, proactive in seeking opportunities, the possibility of employment would certainly be a major issue. Thus, social structures and individual mindset interact in the endeavour of poverty transition.

\section{Wellness is a leading factor in the ability to ease the burden of poverty}

'What could the quality of life of a poor person be? Could there be life quality, enjoyment and pleasure?' Poverty is defined by Haughton and Khandler (2009:21) as deprivation in well-being, predominantly indicating the lack of financial ability to afford basic human needs. Pieterse (2001:99) brings a balance to this point of view by linking human well-being to the principle of shalom in the Old Testament, which was closely connected to material and spiritual well-being. Prilleltensky (2003:19-42) coined the phrase 'wellness' to indicate a satisfactory state of affairs at the personal, relational and collective levels. 'Wellness' is therefore a much broader and inclusive term than 'well-being', which only refers to the personal levels of poverty, life quality and material needs.
Consider, for example, the narratives of our participants. All three participants remained in a situation of poverty after pastoral involvement. Yet, in all three cases a measure of wellness could be identified. In none of the cases were the participants depressed, unhappy or apathetic. In the case of Stanley there were bouts of negativity after alcoholic relapses and even one attempt of suicide. The relapses caused great disappointment because of the stronghold of alcohol abuse. It is therefore safe to assume that the attempted suicide was not caused by the situation of poverty, but rather by a feeling of helplessness against his alcoholism. It would be very difficult to determine at this stage whether it was poverty that started the drinking patterns in early life. Evaluating his narrative it rather seems as though the socialisation with rugby partners and the parents forcing Stanley to return home, thereby forcing him to abandon his great love for the rugby, had a greater influence than negatives feelings about poverty. Whatever the cause, in the pastoral interaction Stanley was always content and grateful for the little that they have. There were even expressions of the belief that God is good and that it is going well with them. Such expressions illustrate that it is possible to have wellness despite the absence of well-being.

This is confirmed by the narrative of the other two participants. Both Hannatjie and Louise have a pleasant and positive attitude. There is no sign of strong negative feelings of hopelessness, bitterness or apathy. Although they do admit that being poor is not easy, they still pursue goals and enjoy what little they have.

According to Louw (2003:213) cura animarum (healing of the soul), which constitutes wellness, is 'a qualitative principle of life as displayed within a very specific disposition or condition before God'. He explains the healing process as being transferred from death to life, which constitutes a new state of being. The regained quality of life is enhanced by interrelatedness and interconnectedness. The movement out of poverty is described as intentional directedness of being towards meaning and ultimate life goals. The important aspect that Louw adds to the discussion on place and wellness is that cura animarum makes it possible to experience wellness whilst still being deprived of material goods or health. Directedness towards a new being would then imply pastoral involvement towards cura animarum which would empower the poor person to be able to experience joy, peace of mind, human dignity and the pursuit of personal goals.

This distinction is vitally important in understanding the needs and predicaments of poor people in their struggle for some life enjoyment, since wellness includes the need for social justice, security, peace, community service, access to education, and shelter. In fact a 'decent life' in general (Prilleltensky 2003:30) could be defined as 'social cohesion' (Prilleltensky 2003:33). Moreira (2003:69-84) and Pieterse (2001:44) add being deprived of power as an overarching concept to describea lack of wellness and an inability to poverty transition. Pieterse (2001:45) explains that powerlessness makes people vulnerable to abuse, violence and oppression. It leads to a life of fear and anxiety. Engelbrecht (1988:20-86) 
argues along the same lines. Deprivation of power and the lack of self determination have a negative influence on the wellness of poor people. They need to have the right to set their own goals for local community development.

\section{More attention should be given to the healing power of space}

Peter Spink (2003:103-118) brings another aspect into the discussion about wellness by combining the concept of poverty with place or space. This includes the place of land. The problem is that it is such a complex issue. Is it true, as it is sometimes suggested (see e.g. Wentzel 2000:92) that there is a link between the brutal murder of farmers and the need for land reform? This is not the place nor is there the space to comment on the need for land possession, but it definitely places the political and psychological need for land reform in South Africa in context and begs for better understanding and co-operation.

By using the paradigm of social constructionism, Spink describes society as complex and multi-dimensional with no clear-cut answers. The paradigm of social constructionism, a postmodern paradigm, leads to an interpretation of society and a social psychology with no fixed rules that may jeopardise the redress of poverty. Spink (2003:138) concludes: 'Community social psychology values the specificity of the community context, and in this, an understanding of poverty in multiple social, political, economic, and psychological components.'

In Louw's approach, the concept of space is broadened to represent an atmospheric environment of positive self-regard and self-understanding. It refers to a quality of being with emotions, attitudes and position, each playing an important part in discovering a new being. Apathy and frustration, for example, are negative emotions creating an unfavourable space. Where apathy presides, poor people have lost the will and the energy to try to do something about their predicament. Thus the expression: 'I am at a dark space.' Within the context of pastoral care as cura animarum, space means 'the creation of an understanding which challenges people to change their attitude' (Louw 2003:214). Healing space constitutes seeing, listening, understanding, acting and supporting, in order to create a healing space and a new being (Louw 2003:216-217).

Applying this theory to the participants in the qualitative research, it could be affirmed that space played an important part in their wellness. Stanley and his wife lived in a room that was in a state of ruins. The ceiling had all but collapsed, the concrete floor disintegrated and some of the walls had such large cracks that you could see through them. To Stanley, this was very upsetting since he wished to have some dignity in his living conditions. He hinted at the discomfort their living conditions caused. Subsequently, a contractor was hired to renovate the place to a reasonable living standard. This had a great positive influence on Stanley in the experience of their poverty. The upgrading of the living space also created, in the words of Louw, a healing space. This illustrates the assumption of Mouton (2004:266-277) that it is possible to be poor and still have human dignity.

Likewise, Louise lived in a small room after her divorce, whilst working as a car watch. Since she became a member of the church she was subsequently appointed as caregiver and cook at a home for the homeless, receiving her own living space and even a small office where she could work with inmates who had needs or complaints. The creation of space enhanced her feeling of wellness and even brought pride and satisfaction.

In the case of Hannatjie she felt extremely uncomfortable living in one of the houses for the homeless together with her father and retarded son. When she was appointed some living space with a few other occupants, she had a kitchen to prepare food and the living space that could ease the tensions of living with other poor people. She reported feeling so much better in the new living space. In all three cases the improvement of living space also enhanced the healing space of wellness.

\section{Religion does play a role in the transition to wellness}

The perception that poor people have negative feelings about God does exist. In his qualitative research, Doss (2011:149) has found that some participants asked questions like: 'Is there a God? Why did God make me? Why does God not hear me? Am I punished for sins?' However, a positive mindset towards God and faith was dominant in the responses. Most participants referred to texts in the Bible that spoke about God's providence over poverty and wealth and that God loves poor people. Mathew 6:33, emphasising priority of God's kingdom over material wealth, functioned prominently. In Mathew 6:25 Jesus reveals the secret of life - that life is worth more than material things. Does this not constitute the difference between well-being and wellness?

Florcy Mabuza associates unbelief with a poverty mentality. She reports that she found it difficult in the context of poverty to believe that God loved her, knew about their predicament and that the promises of his Word would also be true for her. Unbelief was rampant in her life. She writes: 'Unbelief is a stronghold and needs to be dealt with by God's divine power or else you will confess the Word of God forever and not live it' (Mabuza 2010:37). God did indeed deal with this stronghold of disbelief and substituted it with a firm belief in Jesus Christ as Stronghold (Mabuza 2010:95). This made it possible for her to write this inspiring book to help and encourage others to get rid of a poverty mentality.

Streck (2003:2004) reports the narrative of a poor family where the father witnessed to the fact that it was faith that played a major part in helping them cope with the many adversities of poverty. This was indeed the case with all three participants in the qualitative research. Stanley had a similar confession about faith in the Lord and testified that God was 
good to them. He is very fond of gospel songs and included some in his first CD album. He and his wife attend church every Sunday and also participate in church activities.

Hannatjie was also very aware of God's hand over them through the years. She had many hard and trying years in a dark place but never felt aggression against the Lord. Since becoming involved with the congregation she attends church regularly with her father. Louise admitted that she did have negative feelings about God when she was a teenager, but since then she had the knowledge and experience that God would take care of them. Whilst working as car watch during church hours, she was attracted by the spirituality of the congregation and expressed the wish to become a full member which subsequently happened. She is financially supported by the congregation to enable her to attend the worship service every second Sunday.

In all three narratives neither the church in general nor the minister played any role in sustaining the sufferers of poverty. This sad state of affairs is supported by the research of De Klerk (2005:342-357). De Klerk has found that there is a marked and significant absence of prayers for poor people in their plight for poverty transition. It seems to be related to the idea that 'poverty is not our problem'. De Klerk stresses the need that the church should rediscover the power of prayer as a means of pastoral involvement with the poverty-stricken (2005:348). Such prayers could also change the mindset of sufferers, not just to pray for deliverance from poverty, but especially to focus on praising God and seeking his will (2005:349-353).

In evaluating a sermon, Pieterse (2009:268-269) finds that the particular sermon deals with a very vague sense of salvation and lacks a reference to the complex context of poverty. Could this mean that the church's contribution to the plight of poverty in preaching is less than meaningful? It is therefore extremely important to make a serious effort to engage the sermon 'as a vessel of Hope' (Vos 2007:18-19). Since the sermon communicates with a language of love (Vos 2007:24$25)$, it could cause poor people to feel loved, accepted and inspired. These are valuable contributions to the discussion on the power of faith as an agent of poverty transition in the context of the responsibility of the church. In many respects there is a feeling that the church has let poor people down in giving comfort, support and aid in their struggle.

\section{Conclusions}

After reviewing the information, the following conclusions may be drawn:

- The psychology of poverty is a much neglected theme of research in pastoral theology, needing further investigation.

- Social and psychological factors interact in creating or sustaining a context of poverty. Whilst sociological factors seem to be dominant in creating poverty, the mindset of individuals is more predominant in poverty transition.
- Pastoral involvement in the assistance of poor people is vital as a dominant influence in poverty transition. This includes sharing of the Word, prayer and therapy.

- Pastoral involvement must proceed from comfort and guidance to action. A holistic approach to pastoral care and counselling will have to attend to the many needs and predicaments of poor people, guiding and assisting them to well-being and wellness.

- The assumption that poor people must be helped to discover and use their own abilities and assets (the socalled 'Vulnerability Assets Audit') in poverty transition has become apparent. The principle of 'Start with what you have' was applied successfully in the lives of all three participants in the qualitative research.

- In the case of all three participants the pastoral process was significantly enhanced by the involvement with the congregation. The love and acceptance with which the congregation accepted them combated feelings of inferiority, isolation and negative self-worth. It is therefore strongly recommended that poverty transition should be directly linked to congregational involvement.

\section{Acknowledgements Competing interests}

The author declares that he has no financial or personal relationship(s) that may have inappropriately influenced him in writing this article.

\section{References}

Bezuidenhout, J.P. \& Janse Van Rensburg, J., 2006, "n Gereformeerd-narratiewe pastorale terapie', Acta Theologica 26(2), 17-43.

Blattman, C., 2009, Psychology of poverty and temptation, viewed 22 November 2012, from http://chrisblattman.com/2009/09/15/psychology-of-poverty-andtemptation/

Carr, S.C. \& Sloan, T.S. (eds.), 2003, Poverty and psychology, Kluwer Academic/ Plenum Publishers, New York. http://dx.doi.org/10.1007/978-1-4615-0029-2

Charmaz, K., 2006, Constructing Grounded Theory. A practical guide through qualitative analysis, Sage Publications, Thousand Oakes, CA.

Clinebell, H., [1984] 1987, Basic types of pastoral care and counselling, Abingdon Press, Nashville, TN.

Couture, P.D. \& Miller-McLemore, B.J. (eds.), 2003, Poverty, suffering and HIV-AIDS, Cardiff Academic Press, Cardiff.

Curran, L., 2002, 'The psychology of poverty: Professional social work and aid to dependent children in post-war America, 1946-1963', Social Service Review 76(3), 365-386. http://dx.doi.org/10.1086/341180

De Klerk, B.J., 2005, 'Worshipping, prayers and poverty', Ecumenical Review 57(3), 342-357. http://dx.doi.org/10.1111/j.1758-6623.2005.tb00555.x

Doss, G.R., 2011, 'A Malawian Christian theology of wealth and poverty', International Bulletin of Missionary Research 35(3), 148-152.

Engelbrecht, J.F.P., 1988, 'Gemeenskapsontwikkeling in Suid-Afrika: 'n Teoretiese besinning. Werksessie oor kerk en gemeenskapsontwikkeling', pp. 20-86, Ongepubliseerde handleiding.

Gerkin, C.V., 1986, Widening the horizons: Pastoral responses to a fragmented society, Westminster Press, Philadelphia.

Glazer, B.G., 1978, Theoretical sensitivity. Advances in the Methogology of Grounded Theory, Sociology Press, Mill Valey, CA.

Grootart, C., Kanbur, R. \& Oh, Gi-Taik, 1999, The dynamics of poverty: Why some people escape from poverty and others don't. An African case study, World Bank eLibrary, viewed 21 November 2012, from http://elibrary.worldbank.org/content/ workingpaper/10.1596/1813-9450-1499

Haughton, J. \& Khandler, S.R., 2009, Handbook on poverty and inequality, The World Bank, Washington D.C.

Heitink, G., 1993, Practische theologie: Geschiedenis, theorie, handelingsvelden, Kok, Kampen.

Holmes, J., 2011, 'Why can't more poor people escape poverty? A radical new explanation from psychologists', The New Republic, June 06, 2011, pp. 1-2, viewed 22 November 2012, from http://www.tnr.com/article/environmentenergy/89377/poverty-escape-psychology-self-control?page $=0,1$ 
Janse van Rensburg, J., 2009, 'Poverty and pastoral counselling: Design for an extensive research project', Verbum et Ecclesia 30(2), Art. \#180.

Janse van Rensburg, J., 2010, 'A holistic approach to pastoral care and poverty', Verbum et ecclesia 31(1), Art. \#386.

Janse Van Rensburg, J. \& Breed, J., 2011, 'A structured approach to pastoral care and poverty', Verbum et Ecclesia 32(1), Art. \#490, 11 pages.

Johnson, B. \& Christensen, L., 2008, Educational research: Quantitative, qantitative and mixed approaches, 3rd edn., Sage, Thousand Oaks, CA.

Lemmieux, A.F. \& Pratto, F., 2003, 'Poverty and prejudice', in S.C. Carr \& T.S. Sloan (eds.), Poverty and psychology, pp. 147-161, Kluwer Academic/ Plenum Publishers, New York.

Louw, D.J., 1993a, 'Praktiese teologie - 'n fenomenologiese stuiptrekking?', Praktiese Teologie in Suid-Afrika 8(2), 206-209.

Louw, D.J., 1993b, 'Kroniek: Praktiese teologie/pastoraat/gemeentebediening', Praktiese Teologie in Suid-Afrika 8(2), 193-196.

Louw, D.J., 1998, 'Hoe teologies is die praktiese teologie en hoe prakties is die teologie? Ontwerp vir ' $n$ prakties-teologiese hermeneutiek', Praktiese Teologie in Suid Afrika 13(1), 43-63.

Louw, D.J., 1999, Pastoraat as vertolking en ontmoeting, Lux Verbi, Wellington.

Louw, D.J., 2003, 'The healing dynamics of space: Relational and systematic therapy in pastoral care to people suffering from poverty', in P.D. Couture \& B.J. MillerMcLemore (eds.), Poverty, suffering and HIV-AIDS, pp. 213-217, Cardiff Academic McLemore (eds.

Louw, D.J., 2010, "Habitus" in soul care: Towards "spiritual fortigenetics" (parrhesia) in a pastoral anthropology', Acta Theologica 30(2), 67-88.

Mabuza, F., 2010, Poverty mentality: The root of poverty, Zion Publications, Bryanston.

Magezi, V., 2007, HIV/AIDS-poverty and pastoral care and counselling, Sun Press, Stellenbosch.

McClure, B.J., 2012, Moving beyond individualism in pastoral care and counselling Reflections on theory, theology, and practice, Lutterworth Press, Portland.

Meth, C., 2011, 'How not to present poverty research results: The South African case', Southern African Labour and Development Research Unit, Working Paper Series no. 61, SALDU, University of Cape Town, Cape Town.

Moreira, V., 2003, 'Poverty and psychotherapy', in S.C. Carr \& T.S. Sloan (eds.), Poverty and psychology, pp. 69-86, Kluwer Academic/ Plenum Publishers, New York.

Mouton, J., 1993, 'Thomas S Kuhn', in J. Snyman (ed.), Conceptions of social inquiry, pp. 53-75, HSRC, Pretoria.

Mouton, E., 2004, 'Arm en menswaardig? Perspektiewe op God en menswees in 1 Timoteus 2:8-15', Dutch Reformed Theological Journal 45(2), Supplementum, 266-277.

Mullainathan, S., 2011, 'The psychology of poverty', Focus 28(1), 19-22.
Mullainathan, S., 2012, 'The psychology of poverty', viewed 20 November 2012, from http://www.marketplace.org/topics/wealth-poverty/psychology-poverty

Narayan, D. \& Petesch, P. (eds), 2007, Moving out of poverty, Cross-disciplinary perspectives on mobility, vol. 1, The World Bank, Washington D.C.

O'Connor, E.M., 2001, 'Psychology responds to poverty', American Psychological Association 32(9), 81.

Osmer, R.R., 2008, Practical Theology: An introduction, Eerdmans, Grand Rapids, MI.

PerIman, J.E., 2007, 'Elusive pathways out of poverty: Intra- and intergenerational mobility in the favelas of Rio De Janeiro', in D. Narayan \& P. Petesch (eds), Moving out of poverty, Cross-disciplinary perspectives on mobility, vol. 1, pp. 227-271, The World Bank, Washington D.C.

Pieterse, H.J.C., 1993, Praktiese teologie as kommunikatiewe handelingsteorie, RGN Pretoria.

Pieterse, H.J.C., 2001, Preaching in a context of poverty, University of South Africa, Pretoria. PMCid:PMC64867

Pieterse, H.J.C., 2009, 'Prediking wat God ter sprake bring in die Suid-Afrikanse konteks van regstellende aksie', in F.G. Immink \& C. Vos (eds.), God in 'n kantelende wêreld, pp. 250-273, Protea Boekhuis, Pretoria.

Pieterse, H.J.C., 2010, 'Grounded theory approach in sermon analysis of sermons on poverty and directed at the poor as listeners', Acta Theologica 30(2), 113-129.

Prilleltensky, I., 2003, 'Poverty and power', in S.C. Carr \& T.S. Sloan (eds.), Poverty and psychology, pp. 19-44, Kluwer Academic/ Plenum Publishers, New York.

Puidokas, J., 2012, 'The psychology of poverty', viewed 20 November 2012, from http://www.marketplace.org/topics/wealth-poverty/psychology-poverty

Seligman, M., 2011, 'The psychology of poverty', Urbanomics, Wednesday, October 19, 2011, viewed 19 November 2012, from http://gulzar05.blogspot. com/2011/10/psychology-of-poverty.html

Spink, P., 2003, 'Poverty and place', in S.C. Carr \& T.S. Sloan (eds.), Poverty and psychology, pp. 103-120, Kluwer Academic/ Plenum Publishers, New York.

Shafir, E., 2012, 'The psychological poverty trap', HAARETZ, Sunday November 18 2012, Kislew 4, viewed 18 November 2012, from http://www.haaretz.com

Streck, V.S., 2003, 'Domestic violence and alcohol abuse: Challenges for networking among social and pastoral practices', in P.D. Couture \& B.J. Miller-McLemore (eds.), Poverty, suffering and HIV-AIDS, pp. 201-205, Cardiff Academic Press, Cardiff.

Vos, C.J.A., 2007, 'Preaching the language of hope', in C.J.A. Vos, L.C. Hogan \& J.H. Cilliers (eds.), Preaching as a language of hope, pp. 11-28, Studia Homiletica 6 , Protea Book House, Pretoria.

Wentzel, J., 2000, 'The pastoral promise and the political imperative: The plaasroman tradition in an era of land reform', MFS Modern Fiction Studies 46(1), 90-113. http://dx.doi.org/10.1353/mfs.2000.0014 